\title{
The import and export of organic nitrogen species at a Scottish ombrotrophic peatland
}

\author{
Rebecca M. McKenzie ${ }^{1,2}$, Mustafa Z. Özel ${ }^{3}$, J. Neil Cape ${ }^{1}$, Julia Drewer ${ }^{1}$, Kerry J. Dinsmore ${ }^{1}$, Eiko Nemitz ${ }^{1}$, \\ Y. Sim Tang ${ }^{1}$, Netty van Dijk ${ }^{1}$, Margaret Anderson ${ }^{1}$, Jacqueline F. Hamilton ${ }^{3}$, Mark A. Sutton ${ }^{1}$, \\ Martin W. Gallagher ${ }^{2}$, and Ute Skiba ${ }^{1}$ \\ ${ }^{1}$ Centre for Ecology \& Hydrology, Edinburgh, Bush Estate, Penicuik, EH26 0QB, UK \\ ${ }^{2}$ School of Earth, Atmospheric and Environmental Sciences, The University of Manchester, Williamson Building, \\ Oxford Road, Manchester, M13 9PL, UK \\ ${ }^{3}$ Department of Chemistry, The University of York, York, YO10 5DD, UK \\ Correspondence to: Rebecca M. McKenzie (r.mckenzie@lboro.ac.uk)
}

Received: 10 November 2014 - Published in Biogeosciences Discuss.: 9 January 2015

Revised: 26 March 2016 - Accepted: 29 March 2016 - Published: 21 April 2016

\begin{abstract}
Dissolved organic nitrogen (DON) contributes significantly to the overall nitrogen budget, but is not routinely measured in precipitation or stream water. In order to investigate the contribution of DON to the deposition and export of $\mathrm{N}$, precipitation, stream and soil water samples were collected from an ombrotrophic peatland and analysed for DON over a 2-year period. In wet-only deposition DON contributed up to $10 \%$ of the total dissolved nitrogen (TDN) and was the most dominant fraction in soil water $(99 \%)$ and stream water $(75 \%)$. $\mathrm{NH}_{4}^{+}$was the most dominate form of $\mathrm{N}$ in precipitation, with $\mathrm{NO}_{3}^{-}$contributing the least to precipitation, soil water and stream water.

Precipitation and stream DON were qualitatively analysed by a two-dimensional gas chromatograph coupled to a nitrogen chemiluminescence detector $(\mathrm{GC} \times \mathrm{GC}-\mathrm{NCD})$ after trapping onto $\mathrm{C} 18$ solid phase extraction (SPE) cartridges. Ten unique compounds were detected and five identified as pyrrole, benzonitrile, dodecylamine, N-nitrosodipropylamine and decylamine. Five compounds were present in both precipitation and stream samples: pyrrole, benzonitrile and three unidentified compounds. The SPE-extraction efficiency for DON was very low $(11 \%)$, but with improvements DON speciation could become a valuable tool to provide information on its sources and pathways and inform chemical transport models.
\end{abstract}

\section{Introduction}

The total deposition of $\mathrm{N}$ in the UK was estimated to be approximately $330 \mathrm{Gg}$ in 2004, with wet and cloud deposition accounting for approximately $211 \mathrm{Gg}(63.9 \%)$, and the rest consisting of dry deposition (Fowler et al., 2009; Hertel et al., 2011).

Wet deposition of the dissolved inorganic nitrogen (DIN) compounds ammonium $\left(\mathrm{NH}_{4}^{+}\right)$and nitrate $\left(\mathrm{NO}_{3}^{-}\right)$has been studied over many years (Violaki et al., 2010; Cape et al., 2011; Zhang et al., 2012). The former is produced by the dissolution of ammonia gas $\left(\mathrm{NH}_{3}\right)$ and the scavenging of $\mathrm{NH}_{4}^{+}$ aerosol, and the latter by the dissolution of nitric acid gas $\left(\mathrm{HNO}_{3}\right)$ and the scavenging of $\mathrm{NO}_{3}^{-}$aerosol (Russell et al., 1998; Cornell et al., 2003; Tian et al., 2011). The dissolved organic nitrogen (DON) fraction is less well documented due to difficulties in measuring it, but it can be an important fraction of the total dissolved nitrogen (TDN) deposited, and can potentially be biologically available as a source of $\mathrm{N}$ (Russell et al., 1998; Neff et al., 2002; Cornell et al., 2003; Cape et al., 2004). The sources of DON are not well understood, but it is known to be ubiquitous in the environment, present in particulate, gaseous and aqueous phases (Cornell et al., 2003; Cape et al., 2004; Özel et al., 2011). Studies have shown that DON can contribute $30-50 \%$ of the wet deposition of watersoluble N (Neff et al., 2002; Cape et al., 2004, 2011; Zhang et al., 2008, 2012; Cornell, 2011). 
Several atmospheric species of DON are considered hazardous to human health, and appear on the Environment Protection Agency (EPA) hazardous air pollutant list (Özel et al., 2011). Sources of DON are believed to include: pollen, sea spray, soil dust, deposits from fauna and flora, the scavenging of aerosols as well as reactions in the atmosphere between inorganic gaseous nitrogen species and organic compounds (Prospero et al., 1996; Russell et al., 1998; Cornell et al., 2003; Calderon et al., 2007; Zhang et al., 2008; Violaki et al., 2010). Some studies have identified organic N compounds, so that their sources can be traced. Amino acids, urea, aliphatic amines and peptides have all been found in the atmosphere from naturally occurring sources (Calderon et al., 2007; Violaki et al., 2010). The main anthropogenic organic compounds are believed to be N-heterocyclic compounds, nitrophenols and nitro-polycyclic aromatic hydrocarbons (Violaki et al., 2010). Alky amides have also been identified and are believed to result from reactions between $\mathrm{NH}_{3}$ and fatty acids at high temperatures (Cheng et al., 2006); photochemical reactions are believed to be responsible for the presence of alky nitrates and peroxyacyl nitrates (Violaki et al., 2010).

As with wet deposition, $\mathrm{N}$ is present in streams as both DIN and DON, with most focus usually being on the DIN fraction. DIN, in particular $\mathrm{NO}_{3}^{-}$, is often used as an indicator of $\mathrm{N}$ saturation, with higher stream concentrations and changes in seasonal patterns indicating an increase in the leaching of DIN from the catchment (Cundill et al., 2007; Daniels et al., 2012). DON, however, is not routinely measured in spite of being the most dominant fraction in waters draining peatland catchments; it is known to contribute 60$90 \%$ of the TDN load in peatland streams (Yesmin et al., 1995).

The aim of this study was to investigate the contribution of DON to TDN of wet deposition and TDN export via a stream at a typical NW European ombrotrophic peatland over a 2-year period. In addition to this, an attempt was made to identify some of the less polar individual DON compounds present in a selection of precipitation and stream samples. A comparison between possible sources of compounds detected in both the precipitation and stream water was also discussed.

\section{Site and methods}

\subsection{Study area}

Auchencorth Moss (Fig. 1) is an ombrotrophic peat bog located in the south of Scotland, approximately $18 \mathrm{~km}$ southwest of Edinburgh (National Grid Reference NT221562; lat. $55^{\circ} 47^{\prime} 34 \mathrm{~N}$; long. $03^{\circ} 14^{\prime} 35 \mathrm{~W}$ ). The site is used primarily for low intensity sheep grazing (less than one livestock unit $\mathrm{km}^{-2}$ ) and in 2009 a small herd of cows (15-20) also grazed on the site.
The volume of peat in the catchment is estimated to be $\sim 50$ million $\mathrm{m}^{3}$, with depths up to $5 \mathrm{~m}$, and an average depth of $50 \mathrm{~cm}$. The total peat coverage is $\sim 1214$ ha, of which approximately 170 ha is extracted (located $1.75-3.4 \mathrm{~km} \mathrm{W-SW}$ of the monitoring station) (Mitchell and Mykura, 1962; Dinsmore, 2008).

The Black Burn runs SW to NE of the Centre for Ecology and Hydrology (CEH) atmospheric monitoring station at Auchencorth Moss and drains into the North Esk river. It has a catchment area of approximately $335 \mathrm{ha}$, which is fed by numerous tributaries, including one which originates in the area of peat extraction. There are a number of overgrown ditches laid out in parallel, which is evidence of past drainage activities. The elevation of the catchment is approximately $250-300 \mathrm{~m}$ and the main soil type is Histosols ( $85 \%$ coverage), with Gleysol (9\%), Humic Gleysol (3\%) and Cambisols $(3 \%)$ present mostly at the margins of the catchment (Billett et al., 2004).

The vegetation is arranged into numerous hummocks and hollows. The hollows are depressions up to $30 \mathrm{~cm}$ deep and are dominated by blankets of Sphagnum mosses, with various sedges, monocotyledons and other bryophytes also present; the hummocks can be up to $30 \mathrm{~cm}$ high, and although Sphagnum mosses are present, there is a larger density of vascular plants with the dominant species being Deschampsia flexuosa, Eriophorum vaginatum and Juncus effusus. Flechard and Fowler (1998) and Dinsmore (2008) have presented more detailed vegetation information for Auchencorth Moss.

The mean water table depth was determined from nine dip wells located close to the monitoring station (Fig. 1) and was $-14.8 \mathrm{~cm}$, ranging from -52.4 to $7 \mathrm{~cm}$ above the peat surface during the study period (January 2009 to December 2010).

\subsection{Wet-only precipitation}

Auchencorth Moss is a European Monitoring and Evaluation Programme (EMEP) supersite contributing to the Co-operative Programme for Monitoring and Evaluation of the Long-range Transmission of Air Pollutants in Europe (http://www.emep.int/index_facts.html). Precipitation was collected daily using an automated wet-only collector (Eigenbrodt NSA 181/KS, Königsmoor, Germany). A sensor detected when rain fell, opening the lid and allowing rain to be collected in a PTFE-coated funnel draining to refrigerated polyethylene bottles. When rainfall ceased, the sensor closed the lid, protecting the samples from contamination from dry deposition and animal inputs. The collector was kept at $4{ }^{\circ} \mathrm{C}$ by an internal cooling system and samples were manually emptied from the daily collector once a week, when they were stored in a cool room, also at $4{ }^{\circ} \mathrm{C}$. Samples were analysed by ion chromatography (IC) for $\mathrm{NH}_{4}^{+}$and $\mathrm{NO}_{3}^{-}$, following EMEP protocols (http://www.nilu.no/projects/ccc/ manual/index.html). 


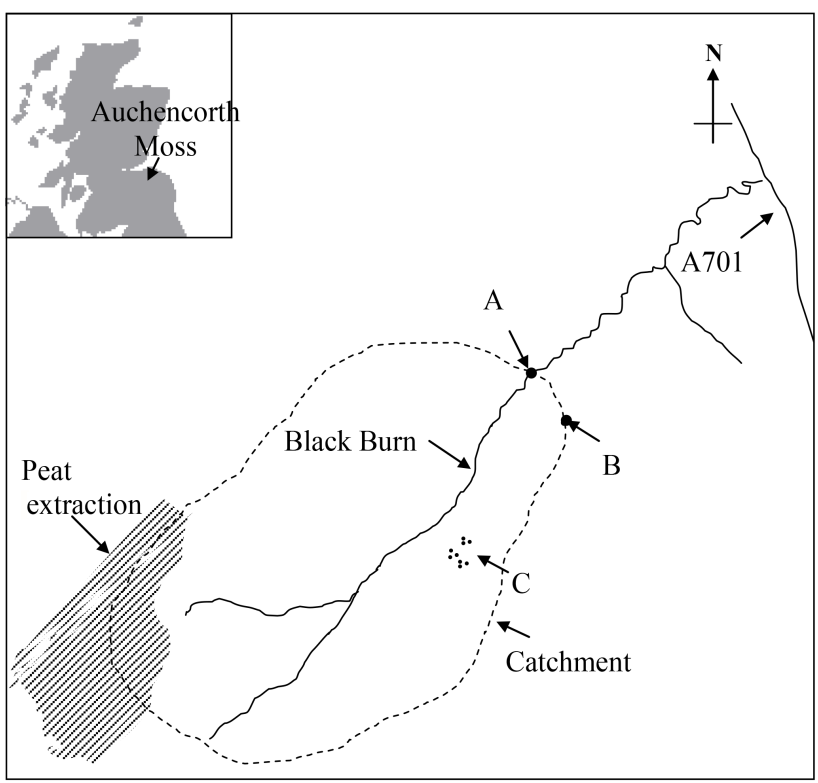

Figure 1. Schematic map of catchment and sampling sites at Auchencorth Moss. A points to the study catchment outlet and stream sampling site, B: monitoring station (wet-only analyser) and C: dip wells. Adapted from Dinsmore et al. (2010).

A Metrohm 761 Compact IC and a Metrohm 733 IC Separation Centre connected in parallel to a Metrohm 766 IC sample processor (Metrohm Ltd., Herisau, Switzerland) measured $\mathrm{NO}_{3}^{-}$and $\mathrm{NH}_{4}^{+}$respectively. $\mathrm{NO}_{3}^{-}$was determined by pumping an eluent solution of $3.2 \mathrm{mM}$ sodium carbonate and $1.0 \mathrm{mM}$ sodium bicarbonate through a Metrosep A Supp 5 column. For $\mathrm{NH}_{4}^{+}$determination, an eluent solution of 24 $\mathrm{mM}$ boric acid, $5 \mathrm{mM}$ tartaric acid and $0.7 \mathrm{mM}$ dipicolinic acid, was pumped through a Metrosep $\mathrm{C} 1$ column. Typical detection limits were $1 \mu \mathrm{mol} \mathrm{N} \mathrm{L}-1$ for both $\mathrm{NO}_{3}^{-}$and $\mathrm{NH}_{4}^{+}$.

Whenever enough precipitation was collected, the EMEP sample was subsampled $(5 \mathrm{~mL})$ for analysis of TDN $(\mathrm{TDN}=\mathrm{DIN}+\mathrm{DON})$. Samples were filtered using Millipore hydrophilic PTFE $(0.45 \mu \mathrm{m}$ pore size $)$ syringe filters prior to freezing and later analysed for TDN by hightemperature catalytic oxidation using an Antek 8060-M Nitrogen-specific HPLC detector (Antek Instruments Inc., Houston, TX, USA). The analysis was conducted in flowinjection mode, in which $20 \mu \mathrm{L}$ samples were introduced into an eluent stream of $10 \%$ methanol in deionised water at a flow rate of $250 \mu \mathrm{L} \mathrm{min}^{-1}$. It was then combusted in oxygen at $1050^{\circ} \mathrm{C}$, producing nitric oxide (NO) which was detected by chemiluminescence. The detection limit for TDN was $\sim 1 \mu \mathrm{mol} \mathrm{NL}{ }^{-1}$. DON was determined by subtracting DIN from TDN.

Subsamples were also analysed for $\mathrm{NO}_{3}^{-}$and $\mathrm{NH}_{4}^{+}$on the IC at CEH and were compared to the EMEP samples. The agreement was good, with an average stan- dard error of $\pm 0.22 \mu \mathrm{mol} \mathrm{NL} L^{-1}$ between $\mathrm{NO}_{3}^{-}$samples and $\pm 1.45 \mu \mathrm{mol} \mathrm{N} \mathrm{L}{ }^{-1}$ between $\mathrm{NH}_{4}^{+}$samples.

The uncertainty of DON is greater than for DIN as a result of errors associated with measuring TDN and DIN compounding (Cornell et al., 2003). A negative bias may result from these combined uncertainties, from DON not being fully converted during the total $\mathrm{N}$ analysis and from losses due to the collection and storage procedure (Russell et al., 1998; Cornell et al., 2003). A positive bias results from setting small negative values of DON to zero. To avoid this bias small negative values of DON were included in the data analyses here. The limit of detection of DON was determined by the summation of the detection limits of the three independent measured concentrations $\left(\mathrm{NH}_{4}^{+}, \mathrm{NO}_{3}^{-}\right.$and $\left.\mathrm{TDN}\right)$ and was $3 \mu \mathrm{mol} \mathrm{N} \mathrm{L}{ }^{-1}$.

\subsection{Soil water}

Soil water was collected once or twice per month from nine dip wells, from which the water table was also measured. They were filtered within $24 \mathrm{~h}$ of collection using Millipore hydrophilic PTFE $(0.45 \mu \mathrm{m}$ pore size $)$ syringe filters and stored frozen until analysis. The dip wells consisted of high-density polyethylene perforated pipes $(0.04 \mathrm{~m}$ diameter) buried in the ground, with rubber bungs to prevent contamination. Samples were analysed for $\mathrm{NH}_{4}^{+}, \mathrm{NO}_{3}^{-}$and TDN by the IC and Antek methods described previously. DON was determined by subtracting DIN from TDN.

\subsection{KCl-extractable mineral N}

Soil cores were collected at a depth of $0-10 \mathrm{~cm}$ at three locations (next to the dip wells) in spring and autumn 2009 and in spring, summer and winter $2010 . \mathrm{NH}_{4}^{+}$and $\mathrm{NO}_{3}^{-}$were extracted from soil samples using $\mathrm{KCl} ; 15 \mathrm{~g}$ of soil were shaken for $1 \mathrm{~h}$ with $50 \mathrm{~mL}$ of $1 \mathrm{M} \mathrm{KCl}$ solution at a rate of $100 \mathrm{rpm}$. Samples were then filtered using Whatman 42 filter papers and frozen prior to analysis by IC. TDN was not measured, so DON could not be determined.

\subsection{Stream water}

Stream-water spot samples were collected from the Black Burn, to the north of the field station, by dipping a $300 \mathrm{~mL}$ glass bottle into the burn once a week. The samples were filtered within $24 \mathrm{~h}$ of collection, using Millipore hydrophilic PTFE $(0.45 \mu \mathrm{m}$ pore size $)$ syringe filters and frozen until ready for analysis. Samples collected from January to October 2009 were analysed for TDN, $\mathrm{NH}_{4}^{+}$and $\mathrm{NO}_{3}^{-}$using a San ${ }^{++}$Automated Wet Chemistry Analyzer/Continuous Flow Analyzer (SKALAR, The Netherlands). Samples from November 2009 to November 2010 were analysed for $\mathrm{NH}_{4}^{+}$, $\mathrm{NO}_{3}^{-}$and TDN using the IC and Antek methods described above. In both cases, DON was determined by subtracting DIN from TDN. 
Discharge was determined from water height using manually calibrated rating curves $\left(R^{2}>0.90\right)$ based on measurements of dilution gauging (K. J. Dinsmore, personal communication, 2012). Pressure transducers were used to measure water height at 10 min intervals. Until April 2009, a Druck PDCR 1830 series pressure transducer was used at the sample site (Fig. 1). After April 2009, an In Situ Inc. Level Troll ${ }^{\circledR}$ pressure transducer located $\sim 2 \mathrm{~km}$ downstream was used.

\subsection{GC $\times$ GC-NCD}

A comprehensive two-dimensional gas chromatography system coupled to a nitrogen chemiluminescence detector $(\mathrm{GC} \times \mathrm{GC}-\mathrm{NCD})$ was used to separate DON into different peaks and identify individual components where possible. To trap DON, samples were extracted by solid phase extraction (SPE), using Superclean ENVI-18 SPE tube $20 \mu \mathrm{m}$ polymeric $\mathrm{C}_{18}$-reverse phase $500 \mathrm{mg}$ SPE cartridges with $3 \mathrm{~mL}$ capacity (SUPELCO, Bellefonte, PA, USA). Cartridges were conditioned with $5 \mathrm{~mL}$ methanol followed by $5 \mathrm{~mL}$ of water at a rate of $2-5 \mathrm{~mL} \mathrm{~min}^{-1}$. Between 5 and $18 \mathrm{~mL}$ of precipitation and 9 and $24 \mathrm{~mL}$ of stream water was passed through the cartridge at a rate of $2-5 \mathrm{~mL} \mathrm{~min}^{-1}$. The cartridge was thoroughly dried under vacuum for $\sim 30 \mathrm{~min}$, eluted with $5 \mathrm{~mL}$ dichloromethane (DCM) and then concentrated in a stream of nitrogen to a volume of $\sim 0.1 \mathrm{~mL}$ prior analysis by $\mathrm{GC} \times \mathrm{GC}-\mathrm{NCD}$. We investigated the extraction efficiency retrospectively on rainwater and river water samples collected in October 2015 from the same locations the precipitation and stream-water samples were collected from in 2009 and 2010, and analysed these for DIN and TDN as described in Sect. 2.2. As expected the C18 SPE cartridges did not retain $\mathrm{NH}_{4}$ and $\mathrm{NO}_{3}$ on the SPE cartridges, but unfortunately the retention of DON was also low ( $9 \%$ for the precipitation and $18 \%$ for the river waters).

The GC $\times$ GC-NCD was an Agilent 7890 GC coupled with an Agilent 255 NCD (Agilent Technologies, Palo Alto, CA, USA). $1 \mu \mathrm{l}$ extracts were injected in pulsed splitless mode at $280^{\circ} \mathrm{C}$ and a pressure of 30 psi for 2 min, using a Gerstel automated liquid injector (Gerstel, Mulheim an der Ruhr, Germany). The first dimension column was a non-polar BPX5 ( $30 \mathrm{~m} \times 0.32 \mathrm{~nm}$ i.d. $\times 0.25 \mu \mathrm{m}$ film thicknesses $)$, set to an initial temperature of $55^{\circ} \mathrm{C}$ for $1 \mathrm{~min}$. The temperature was then increased at a rate of $5^{\circ} \mathrm{C} \mathrm{min}^{-1}$ until $305^{\circ} \mathrm{C}$, at which point it was isothermally held for $1 \mathrm{~min}$. The second column was a BPX50 $(1.5 \mathrm{~m} \times 0.10 \mathrm{~mm}$ i.d. $\times 0.10 \mu \mathrm{m}$ film thickness) set to an initial temperature of $70^{\circ} \mathrm{C}$ for $1 \mathrm{~min}$, then increasing the temperature at a rate of $5^{\circ} \mathrm{C} \mathrm{min}{ }^{-1}$ until $320^{\circ} \mathrm{C}$, at which point it was isothermally held for $1 \mathrm{~min}$. Both columns were from SGE Analytical Science (VIC, Australia). Helium was used as a carrier gas at a constant flow of $1 \mathrm{~mL} \mathrm{~min}^{-1}$ and the data were collected at $50 \mathrm{~Hz}$. Pyrolysis was carried out at $900{ }^{\circ} \mathrm{C}$ with a hydrogen flow rate of $4 \mathrm{~mL} \mathrm{~min}^{-1}$ and oxygen flow rate of $10 \mathrm{~mL} \mathrm{~min}^{-1}$.
The detector shows an equimolar response regardless of the chemical state of the organic nitrogen (except azo compounds), allowing nitrogen-containing compounds to be quantified without the need for a separate calibration standard for each compound (Yan, 2002; Özel et al., 2011). Details of the optimisation of the NCD response and the analytical performance with respect to equimolar response using standards was evaluated by Özel et al. (2011).

\section{Results}

\subsection{Meteorology}

Total rainfall was determined from the volume of rain collected in the wet-only analyser. In 2009 the total rainfall was $902 \mathrm{~mm}$ with monthly totals varying from $16 \mathrm{~mm}$ in February to $180 \mathrm{~mm}$ in November. The mean monthly temperature varied from $0.5^{\circ} \mathrm{C}$ in December to $13.7^{\circ} \mathrm{C}$ in July, with a yearly mean of $7.6^{\circ} \mathrm{C}$. In 2010 the total rainfall was $732 \mathrm{~mm}$ with monthly totals varying from $21 \mathrm{~mm}$ in May to $128 \mathrm{~mm}$ in November. However, a significant amount of snow fell, which was not recorded by the wet-only collector. Based on the ratio of discharge and precipitation (Dinsmore et al., 2013; Skiba et al., 2013) it was estimated that snow accounted for an additional $291 \mathrm{~mm}$, making the total precipitation collected for 2010 approximately $1023 \mathrm{~mm}$. The mean monthly temperature varied from $-2.0^{\circ} \mathrm{C}$ in December to $13.6^{\circ} \mathrm{C}$ in July, with a yearly mean of $6.6^{\circ} \mathrm{C}$.

\subsection{Wet-only $\mathbf{N}$ deposition}

Figure 2 shows the volume-weighted monthly mean concentrations of $\mathrm{N}$ in precipitation. The temporal variation of $\mathrm{NH}_{4}^{+}$ and $\mathrm{NO}_{3}^{-}$follow a similar pattern, with DON differing. In both 2009 and 2010 (Table 1), $\mathrm{NH}_{4}^{+}$was the dominant component of wet-only deposition with annual mean concentrations of $27.2 \mu \mathrm{mol} \mathrm{N} \mathrm{L}{ }^{-l}$ (58\% of TDN) and $30.7 \mu \mathrm{mol} \mathrm{N} \mathrm{L}{ }^{-l}$ (53\% of TDN) respectively. The contribution of $\mathrm{NO}_{3}^{-}$was greater in 2010 than in 2009, with mean concentrations of $15.0 \mu \mathrm{mol} \mathrm{N} \mathrm{L}{ }^{-l}$ (32\% of TDN) in 2009 and $22.7 \mu \mathrm{mol} \mathrm{N} \mathrm{L}{ }^{-l}$ (39\% of TDN) in 2010. Although DON contributed the least to annual concentrations in both years, on a monthly timescale there were a few occasions when DON exceeded $\mathrm{NO}_{3}^{-}$(March 2009, June 2009, August 2009 and October 2010). A loose seasonal pattern was observed for $\mathrm{NH}_{4}^{+}$and $\mathrm{NO}_{3}^{-}$, with peak concentrations occurring between January and June, especially in 2010. DON has no clear seasonal pattern, although the lowest concentrations seem to occur in the winter months (November-January). A weak, but significant correlation was found between $\mathrm{NH}_{4}^{+}$and $\mathrm{NO}_{3}^{-}$in 2009 $\left(R^{2}=0.45, p<0.001\right)$ and a slightly stronger correlation in $2010\left(R^{2}=0.62, p<0.001\right)$. No correlations were observed between $\mathrm{NH}_{4}^{+}$, DON, temperature, rainfall or precipitation; 


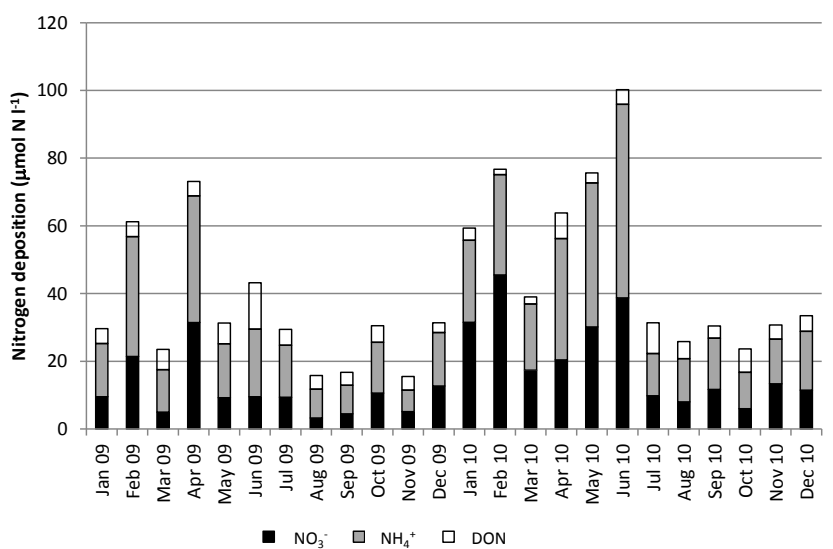

Figure 2. Volume-weighted monthly average concentrations of $\mathrm{NH}_{4}^{+}$(grey), $\mathrm{NO}_{3}^{-}$(black) and DON (white) in wet-only precipitation.

$\mathrm{NO}_{3}^{-}$, DON, temperature, rainfall or precipitation or DON, temperature, rainfall or precipitation.

\subsection{Soil water and $\mathrm{KCl}$-extractable $\mathbf{N}$}

As expected for a peatland, DON dominates TDN concentrations in the soil water. The contribution of DON to TDN was higher in 2010 at $99 \%$ compared to $85 \%$ in 2009 (Table 2). Mean annual $\mathrm{NO}_{3}^{-}$concentrations were $1.2 \mu \mathrm{mol} \mathrm{NL} \mathrm{N}^{-1}(2 \%$ of TDN) in 2009 and $0.2 \mu \mathrm{mol} \mathrm{NL}^{-1}$ ( $0.3 \%$ of TDN) in 2010. Mean annual $\mathrm{NH}_{4}^{+}$concentrations were also larger in $2009\left(8.6 \mu \mathrm{mol} \mathrm{N} \mathrm{L}^{-1}\right)$ than in $2010\left(0.2 \mu \mathrm{mol} \mathrm{N} \mathrm{L}^{-1}\right)$. The contribution of $\mathrm{NH}_{4}^{+}$to TDN was thus much larger in 2009 at $13 \%$ and just $0.4 \%$ in 2010 . Due to data gaps caused by dip wells remaining empty in low rainfall periods or frozen in winter 2010, it was difficult to assess seasonal patterns.

Soil extractions of $\mathrm{NO}_{3}^{-}$and $\mathrm{NH}_{4}^{+}$using $1 \mathrm{M} \mathrm{KCl}$ on two occasions in 2009 and 3 three occasions in 2010 showed similar trends; no detectable $\mathrm{NO}_{3}^{-}$and $\mathrm{NH}_{4}^{+}$concentrations of $29 \pm 12$ and $39 \pm 20 \mu \mathrm{mol} \mathrm{N} \mathrm{L}^{-1}$ for 2009 and 2010 respectively.

\subsection{Concentration and forms of $\mathrm{N}$ in stream water}

DON is the dominant $\mathrm{N}$ species found in the stream water. Monthly mean discharge-weighted concentrations contributed on average $74.6 \%$ (in 2009) and $74.3 \%$ (in 2010) to TDN; with the highest concentrations in summer/autumn, however no clear seasonal pattern was evident (Fig. 4, Table 3). Monthly mean discharge-weighted concentrations of $\mathrm{NO}_{3}^{-}$ranged from 0.0 to $13.7 \mu \mathrm{mol} \mathrm{N} \mathrm{L}{ }^{-1}$ in 2009 and 0.0 to $15.2 \mu \mathrm{mol} \mathrm{N} \mathrm{L}^{-1}$ in 2010 . Annual mean concentrations were $2.3 \mu \mathrm{mol} \mathrm{N} \mathrm{L}{ }^{-1}$ in 2009 and $4.5 \mu \mathrm{mol} \mathrm{N} \mathrm{L}^{-1}$ in 2010. In 2009, concentrations varied seasonally; the largest $\mathrm{NO}_{3}^{-}$concentrations were measured during the cooler months and the smallest during the warmer months. In summer 2009 there was no detectable $\mathrm{NO}_{3}^{-}$. In 2010 stream-water $\mathrm{NO}_{3}^{-}$concentrations

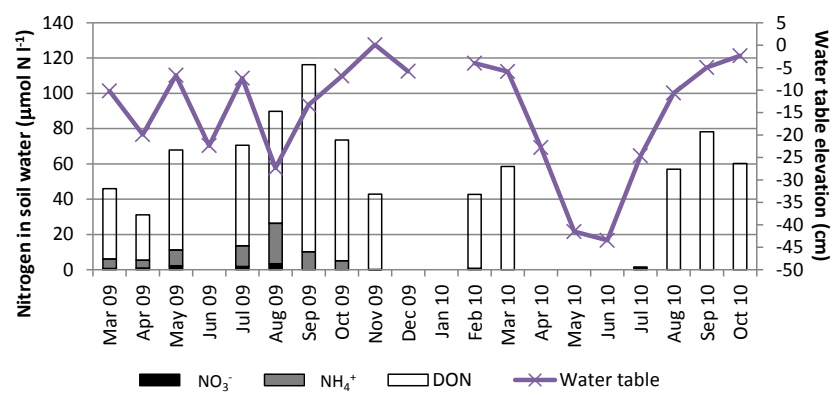

Figure 3. Monthly concentrations of $\mathrm{NH}_{4}^{+}$(grey), $\mathrm{NO}_{3}^{-}$(black) and DON (white) in soil water. The line represents monthly water table elevation. The June 2009 sample was misplaced and December 2009 and January 2010 were frozen; the remaining blank spaces indicate that the dip wells were dry on the day of collection.

initially followed a similar pattern as in 2009 , with concentrations increasing during the winter months and decreasing as temperature increased and summer approached. However, there was a large increase in $\mathrm{NO}_{3}^{-}$concentrations in June and July 2010. Consequently, average annual $\mathrm{NO}_{3}^{-}$concentrations in 2010 were nearly double those in 2009 , contributing $6.6 \%$ of TDN compared to $3.6 \%$ of TDN (Table 3 ). Monthly median concentrations for $\mathrm{NO}_{3}^{-}$for the whole period showed a similar pattern to monthly discharge-weighted mean concentrations, with the exception of June 2010, which is reduced to a summer low of $0 \mu \mathrm{mol} \mathrm{N} \mathrm{L}{ }^{-1}$, suggesting the monthly mean value was skewed by an unusually large value. Median concentrations made little difference to the July 2010 maximum. July 2010 also showed a maximum in the mean concentrations of DON and $\mathrm{NH}_{4}^{+}$.

Monthly mean discharge-weighted concentrations of $\mathrm{NH}_{4}^{+}$ ranged from 5.4 to $21.9 \mu \mathrm{mol} \mathrm{N} \mathrm{L}^{-1}$ with an annual mean of $14.1 \mu \mathrm{mol} \mathrm{N} \mathrm{L}{ }^{-1}$ in 2009 , and 0.0 to $52.3 \mu \mathrm{mol} \mathrm{N} \mathrm{L}^{-1}$ with an annual mean of $12.9 \mu \mathrm{mol} \mathrm{N} \mathrm{L}^{-1}$ in 2010 . Concentrations of $\mathrm{NH}_{4}^{+}$were consistently higher than $\mathrm{NO}_{3}^{-}$and there was no clear seasonal pattern. No correlation was observed between $\mathrm{NH}_{4}^{+}, \mathrm{NO}_{3}^{-}$, DON, discharge, temperature, rainfall (both air and stream) or precipitation.

\subsection{DON speciation by GC x GC-NCD}

Tables 4 and 5 display breakdowns of the individual DON compounds detected by the GC $\times$ GC-NCD and their respective concentrations for precipitation and stream water. The plasticiser N-butyl-benzenesulphonamide (not included in tables) was a prominent compound in all samples, with extremely high concentrations, sometimes higher than TDN detected in the precipitation measured by the Antek. We assume that the N-butyl-benzenesulphonamide detected was most likely to be a sampling contaminant from the storage bottles during storage in the freezer prior to analysis or from SPE extraction tubes by reaction with the DCM. This contamination was not detected in blank water samples (deionised 
Table 1. Statistics of annual concentrations of $\mathrm{NH}_{4}^{+}, \mathrm{NO}_{3}^{-}$, DON and TDN for 2009 and 2010 in wet-only precipitation. Values are based on individual samples collected over the 2-year period. $N^{*}$ indicates the number of samples collected.

\begin{tabular}{lllll}
\hline & $\begin{array}{l}\mathrm{NO}_{3}^{-} \\
\mu \mathrm{mol} \mathrm{N} \mathrm{L}\end{array}$ & $\begin{array}{l}\mathrm{NH}_{4}^{+} \\
\mu \mathrm{mol} \mathrm{N} \mathrm{L}\end{array}$ & $\begin{array}{l}\mathrm{DON} \\
\mu \mathrm{mol} \mathrm{N} \mathrm{L}\end{array}$ & $\begin{array}{l}\mathrm{TDN} \\
\mu \mathrm{mol} \mathrm{NL}^{-1}\end{array}$ \\
\hline 2009 & & & & \\
\hline Mean & 15 & 27 & 5 & 47 \\
Min & $<\mathrm{LOD}$ & $<\mathrm{LOD}$ & $<\mathrm{LOD}$ & 6 \\
Max & 148 & 273 & 50 & 426 \\
Standard deviation & 21 & 35 & 4 & 50 \\
$N^{*}$ & 227 & 227 & 63 & 63 \\
$\%$ TDN & 32 & 58 & 10 & 100 \\
\hline 2010 & & & & \\
\hline Mean & 23 & 31 & 5 & 58 \\
Min & 2 & 2 & $<\mathrm{LOD}$ & 8 \\
Max & 260 & 218 & 45 & 483 \\
Standard deviation & 30 & 33 & 5 & 59 \\
$N^{*}$ & 169 & 169 & 63 & 63 \\
$\%$ TDN & 39 & 53 & 8 & 100 \\
\hline
\end{tabular}

Table 2. Statistics of annual concentrations of $\mathrm{NH}_{4}^{+}, \mathrm{NO}_{3}^{-}$, DON and TDN for 2009 and 2010 in soil water. Values are based on individual samples collected from dip wells over the 2-year period. $N^{*}$ indicates the number of samples collected.

\begin{tabular}{lllll}
\hline & $\begin{array}{l}\mathrm{NO}_{3}^{-} \\
\mu \mathrm{mol} \mathrm{N}\end{array}$ & $\begin{array}{l}\mathrm{NH}_{4}^{+} \\
\mu \mathrm{mol} \mathrm{N} \mathrm{L}\end{array}$ & $\begin{array}{l}\mathrm{DON} \\
\mu \mathrm{mol} \mathrm{N} L^{-1}\end{array}$ & $\begin{array}{l}\mathrm{TDN} \\
\mu \mathrm{mol} \mathrm{NL}^{-1}\end{array}$ \\
\hline 2009 & & & & \\
\hline Mean & 1 & 9 & 57 & 67 \\
Min & $<\mathrm{LOD}$ & $<\mathrm{LOD}$ & 11 & 11 \\
Max & 6 & 91 & 319 & 389 \\
Median & 0 & 1 & 48 & 54 \\
Standard deviation & 2 & 15 & 44 & 54 \\
$N^{*}$ & 72 & 72 & 72 & 72 \\
$\%$ of TDN & 2 & 13 & 85 & 100 \\
\hline 2010 & & & & \\
\hline Mean & $<\mathrm{LOD}$ & $<\mathrm{LOD}$ & 59 & 60 \\
Min & $<\mathrm{LOD}$ & $<\mathrm{LOD}$ & 23 & 23 \\
Max & 8 & 7 & 285 & 285 \\
Median & 0 & 0 & 44 & 44 \\
Standard deviation & 1 & 1 & 43 & 43 \\
$N^{*}$ & 54 & 54 & 45 & 45 \\
$\%$ of TDN & 0.3 & 0.4 & 99.3 & 100 \\
\hline
\end{tabular}

water) or by the Antek as samples run on this machine were filtered directly into glass vials for storage before analysis. The source of this contamination is discussed later and the compound was thus excluded from the results.

In 13 of the 31 precipitation samples and 2 of the 21 stream samples, no DON compounds were detected or the peaks were too small to be distinguishable from background noise. The limit of detection (LOD) using the optimised method was determined between 0.16 and $0.27 \mathrm{pgN}$ using $\mathrm{GC} \times \mathrm{GC}$ NCD of standard mixtures (Özel et al., 2011).

Peak identification was carried out by comparing the two retention times $\left(R_{t 1}\right.$ and $\left.R_{t 2}\right)$ of the peaks observed in the samples with the retention times of known standards. This could lead to some misidentification, however coelution is greatly reduced using $\mathrm{GC} \times \mathrm{GC}$ and there is very good retention time stability between runs. Several peaks, consistently present in some samples, could not be identified as they did 
Table 3. Statistics of annual concentrations of $\mathrm{NH}_{4}^{+}, \mathrm{NO}_{3}^{-}$, DON and TDN for 2009 and 2010 in stream water. Values are based on individual samples collected over the 2-year period. $N^{*}$ indicates the number of samples collected.

\begin{tabular}{lllll}
\hline & $\begin{array}{l}\mathrm{NO}_{3}^{-} \\
\mu \mathrm{mol} \mathrm{NL}\end{array}$ & $\begin{array}{l}\mathrm{NH}_{4}^{+} \\
\mu \mathrm{molNL} \mathrm{L}^{-1}\end{array}$ & $\begin{array}{l}\mathrm{DON} \\
\mu \mathrm{mol} \mathrm{NL} \mathrm{L}^{-1}\end{array}$ & $\begin{array}{l}\mathrm{TDN} \\
\mu \mathrm{mol} \mathrm{NL}{ }^{-1}\end{array}$ \\
\hline 2009 & & & & \\
\hline Mean & 2 & 14 & 48 & 65 \\
Min & $<\mathrm{LOD}$ & 5 & 10 & 25 \\
Max & 14 & 22 & 96 & 118 \\
Median & 0 & 14 & 47 & 64 \\
Standard deviation & 4 & 3 & 21 & 21 \\
$N^{*}$ & 43 & 43 & 43 & 43 \\
$\%$ of TDN & 4 & 22 & 75 & 100 \\
\hline 2010 & & & & \\
\hline Mean & 5 & 13 & 50 & 67 \\
Min & $<\mathrm{LOD}$ & $<\mathrm{LOD}$ & 16 & 16 \\
Max & 15 & 52.3 & 104 & 145 \\
Median & 4 & 7.9 & 46 & 59 \\
Standard deviation & 4 & 13.8 & 20 & 31 \\
$N^{*}$ & 48 & 48 & 48 & 48 \\
$\%$ of TDN & 7 & 19 & 74 & 100 \\
\hline
\end{tabular}

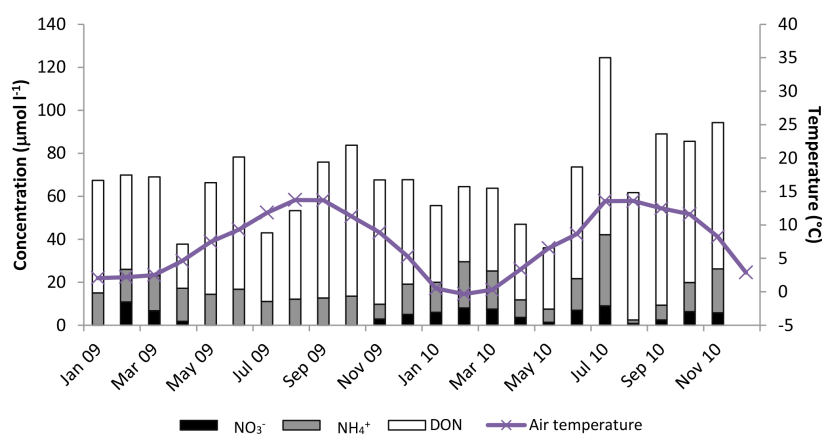

Figure 4. Discharge-weighted monthly mean concentrations of $\mathrm{NH}_{4}^{+}$(grey), $\mathrm{NO}_{3}^{-}$(black) and DON (white) in stream water. The line represents mean monthly air temperature.

not match any of the retention times of the standards available, and therefore were labelled "Unknown A-F". In total 10 unique compounds were found to be present in the stream and precipitation, of which only five could be identified. Tables 4 and 5 present a summary of the compounds identified in precipitation and stream-water DON respectively. Both the precipitation and the stream water contained eight distinct compounds, five of which were in common.

The most common compound identified in the precipitation samples was Unknown E, present in 10 samples, followed by Unknown D in six samples and Unknown $\mathrm{B}$ in five samples, with mean concentrations of $0.3,0.14$ and $0.2 \mu \mathrm{mol} \mathrm{NL} \mathrm{N}^{-1}$. Two precipitation samples contained pyrrole, with a mean concentration of $0.03 \mu \mathrm{mol} \mathrm{NL}^{-1}$. Unknown $\mathrm{F}$ was in 3 samples (mean concentrations of
$0.1 \mu \mathrm{mol} \mathrm{N} \mathrm{L}{ }^{-1}$ ), dodecylamine was in two samples (mean concentration of $0.02 \mu \mathrm{mol} \mathrm{N} \mathrm{L} \mathrm{L}^{-1}$ ) and Unknown $\mathrm{C}$ was in one sample $\left(0.02 \mu \mathrm{mol} \mathrm{N} \mathrm{L}{ }^{-1}\right)$. The precipitation samples did not contain Unknown A, N-nitrosodipropylamine or decylamine, which were found in the stream samples.

The most common compound identified in the stream samples was Unknown A, the mean concentration was $2.0 \mu \mathrm{mol} \mathrm{NL}^{-1}$ (Table 5). Pyrrole was the next most common compound, found in 18 of the stream samples, with a mean concentration of $1.2 \mu \mathrm{mol} \mathrm{N} \mathrm{L}^{-1}$. Unknowns $\mathrm{E}$ and $\mathrm{F}$ both appeared in nine stream samples, with mean concentrations of 0.5 and $0.4 \mu \mathrm{mol} \mathrm{N} \mathrm{L}{ }^{-1}$. N-nitrosodipropylamine (NDPA) was present in 4 stream samples, followed by Unknown $\mathrm{B}$ and decylamine in three stream samples. Mean concentrations were $0.2 \mu \mathrm{mol} \mathrm{N} \mathrm{L}{ }^{-1}$ for all three compounds. Unknown D, Unknown C and dodecylamine, present in the precipitation samples, were absent from the stream samples.

In both the stream and precipitation samples, only one sample contained benzonitrile, with means of $0.01 \mu \mathrm{mol} \mathrm{N} \mathrm{L}{ }^{-1} \quad$ (precipitation) and $0.1 \mu \mathrm{mol} \mathrm{NL}^{-1}$ (stream).

Figures 5a and 6a display breakdowns of the monthly means of individual DON compounds extracted with the $\mathrm{C} 18$ SPE cartridges prior to identification by the $\mathrm{GC} \times \mathrm{GC}-\mathrm{NCD}$ method and the remaining DON measured by Antek for precipitation and stream water respectively. Figures $5 \mathrm{~b}$ and $6 \mathrm{~b}$ show the monthly means of individual DON compounds detected by the GC $\times$ GC-NCD only, to make this fraction more visible. In both cases, the majority of DON was not unidentified, contributing a mean of 91 and $82 \%$ of total DON 
Table 4. Summary of compounds and their concentrations $\left(\mu \mathrm{molNL} \mathrm{N}^{-1}\right.$ ) detected by the GC $\times \mathrm{GC}-\mathrm{NCD}$, and overall DON concentrations $\left(\mu \mathrm{mol} \mathrm{N} \mathrm{L}^{-1}\right)$ derived from TDN-DIN in precipitation samples. Samples collected on dates shaded in grey did not contain compounds at measurable concentrations by the GC $\times$ GC-NCD. Blank spaces indicate a value below the detection limit. $R_{t 1}$ and $R_{t 2}$ are retention times in seconds for the first and second GC columns.

\begin{tabular}{|c|c|c|c|c|c|c|c|c|c|}
\hline $\begin{array}{l}\text { Sample } \\
R_{t 1} / R_{t 2}\end{array}$ & $\begin{array}{r}\text { DON } \\
(\mathrm{TDN}-\mathrm{DIN})\end{array}$ & $\begin{array}{c}\text { Pyrrole } \\
375 / 1.24\end{array}$ & $\begin{array}{c}\text { Benzonitrile } \\
825 / 1.8\end{array}$ & $\begin{array}{c}\text { Unknown B } \\
11.45 / 1.52\end{array}$ & $\begin{array}{c}\text { Unknown C } \\
1218 / 1.48\end{array}$ & $\begin{array}{c}\text { Dodecylamine } \\
1590 / 1.5\end{array}$ & $\begin{array}{c}\text { Unknown D } \\
1615 / 1.7\end{array}$ & $\begin{array}{c}\text { Unknown E } \\
1910 / 1.7\end{array}$ & $\begin{array}{c}\text { Unknown F } \\
2200 / 2.09\end{array}$ \\
\hline 09/07/2010 & 9.2 & & & & & & & 1.6 & 1.7 \\
\hline $13 / 07 / 2010$ & 13.8 & & 0.4 & & & & 0.5 & & \\
\hline $14 / 07 / 2010$ & 6.5 & & & & & & & & \\
\hline $15 / 07 / 2010$ & 5.5 & & & & & & & & \\
\hline 09/08/2010 & 9.4 & & & & & & 0.6 & & 1.8 \\
\hline $12 / 08 / 2010$ & 6.5 & & & & & & & 0.3 & 0.3 \\
\hline $20 / 08 / 2010$ & 3.5 & 0.2 & & & & & & 0.6 & \\
\hline $23 / 08 / 2010$ & 2.4 & & & & & & & 0.5 & \\
\hline 06/09/2010 & 3.1 & & & & & & & 1.9 & \\
\hline $13 / 09 / 2010$ & 3.2 & & & & & & & & \\
\hline $14 / 09 / 2010$ & 5.8 & & & & & & & & \\
\hline $18 / 09 / 2010$ & 3.3 & & & & & & & & \\
\hline $01 / 10 / 2010$ & 0.5 & & & & & & & & \\
\hline $05 / 10 / 2010$ & 1.0 & 0.7 & & 2.0 & & & & & \\
\hline $06 / 10 / 2010$ & -2.4 & & & & & & & & \\
\hline $18 / 10 / 2010$ & 2.1 & & & 0.7 & & & 0.7 & & \\
\hline $21 / 10 / 2010$ & 19.8 & & & 1.3 & & 0.5 & 2.4 & & \\
\hline $24 / 10 / 2010$ & 7.1 & & & 1.2 & & & & & \\
\hline $25 / 10 / 2010$ & 1.2 & & & 0.5 & & 0.7 & 1.8 & & \\
\hline $26 / 10 / 2010$ & 5.8 & & & & 0.5 & & & 0.9 & \\
\hline $01 / 11 / 2010$ & 3.9 & & & & & & & & \\
\hline $02 / 11 / 2010$ & 7.0 & & & & & & 0.1 & & \\
\hline $03 / 11 / 2010$ & 5.1 & & & & & & & 0.4 & \\
\hline $04 / 11 / 2010$ & 2.9 & & & & & & & & \\
\hline $05 / 11 / 2010$ & 3.9 & & & & & & & & \\
\hline $06 / 11 / 2010$ & 4.6 & & & & & & & & \\
\hline $08 / 11 / 2010$ & 9.9 & & & & & & & 0.4 & \\
\hline 09/11/2010 & -2.4 & & & & & & & & \\
\hline $10 / 11 / 2010$ & -0.2 & & & & & & & & \\
\hline $11 / 11 / 2010$ & 5.0 & & & & & & & 0.7 & \\
\hline $13 / 11 / 2010$ & 6.1 & & & & & & & 0.6 & \\
\hline
\end{tabular}

detected in precipitation and stream water respectively. In the precipitation samples, Unknown $\mathrm{E}$ is the only compound present in all five sampling months and is the only compound identified in September. October had the most identified compounds present, with six of the eight compounds measured (Fig. 5b). In the stream samples, pyrrole and Unknown A were present in all four sampling months. October also had the most identified compounds present, with seven of the eight compounds present (Fig. 4).

\section{Discussion}

\subsection{The composition of $\mathrm{N}$ in precipitation}

Cape et al. (2004) studied several sites in the UK on a range of land uses and noted an annual cycle for DIN and DON, with peak concentrations for $\mathrm{NH}_{4}^{+}$and $\mathrm{NO}_{3}^{-}$occurring in April-June from 2000 to 2002 and a DON peak occurring later (June-August from 2000 to 2002). Both DIN and DON showed minima in winter. The data presented here are sim- ilar, but with earlier DIN maxima (February-April in 2009 and February-June in 2010), followed by lower values in the autumn and beginning of winter. DON also peaked earlier than reported by Cape at al. (2004) but roughly a month after DIN peaked in both 2009 and 2010. Generally, sources of $\mathrm{NH}_{4}^{+}$in precipitation tend to be of agricultural origin and sources of $\mathrm{NO}_{3}^{-}$in precipitation from combustion activities (Cape et al., 2011). Although Auchencorth Moss is located in a rural setting and with minimal agricultural activity on the peatland itself, there are several chicken farms in the area. Chickens farms emit ammonia $\left(\mathrm{NH}_{3}\right)$, which when dissolved in rainwater, produces $\mathrm{NH}_{4}^{+}$(Schlesinger, 1997). $\mathrm{NH}_{4}^{+}$also makes up a large fraction of atmospheric aerosols and is often transported further downwind of its source (Nieder and Benbi, 2008), where it can then be washed out and deposited by precipitation.

Sources of $\mathrm{NO}_{3}^{-}$include motor vehicles and stationary combustion sources (power stations, domestic heating) following atmospheric oxidation of the emitted nitrogen oxides. As a secondary pollutant, nitric acid and nitrates are 
Table 5. Summary of compounds and their concentrations $\left(\mu \mathrm{molNL} \mathrm{L}^{-1}\right.$ ) detected by the GC $\times \mathrm{GC}-\mathrm{NCD}$, and DON concentrations $\left(\mu \mathrm{mol} \mathrm{N} \mathrm{L}{ }^{-1}\right.$ ) detected by Antek in stream-water samples. Samples collected on dates shaded in grey did not contain compounds at measurable concentrations by the GC $\times$ GC-NCD. Blank spaces indicate a measured value of below the detection limit. $R_{t 1}$ and $R_{t 2}$ are retention times in seconds for the first and second GC columns.

\begin{tabular}{|c|c|c|c|c|c|c|c|c|c|}
\hline $\begin{array}{l}\text { Sample } \\
R_{t 1} / R_{t 2}\end{array}$ & $\begin{array}{r}\text { DON } \\
(\text { TDN-DIN) }\end{array}$ & $\begin{array}{c}\text { Pyrrole } \\
375 / 1.24\end{array}$ & $\begin{array}{c}\text { Unknown A } \\
415 / 1.24\end{array}$ & $\begin{array}{l}\text { Benzonitrile } \\
825 / 1.8\end{array}$ & $\begin{array}{c}\text { N-nitrosodipropylamine } \\
970 / 1.4\end{array}$ & $\begin{array}{c}\text { Unknown B } \\
11.45 / 1.52\end{array}$ & $\begin{array}{l}\text { Decylamine } \\
1295 / 1.64\end{array}$ & $\begin{array}{c}\text { Unknown E } \\
1910 / 1.7\end{array}$ & $\begin{array}{l}\text { Unknown F } \\
2200 / 2.09\end{array}$ \\
\hline $11 / 08 / 2010$ & 45.9 & 1.3 & 3.2 & & & & & 0.9 & \\
\hline $19 / 08 / 2010$ & 54.8 & 0.2 & 0.3 & & 1.2 & & & & \\
\hline $26 / 08 / 2010$ & 85.2 & 0.7 & 2.7 & 3.0 & & & & & \\
\hline $10 / 09 / 2010$ & 30.5 & 0.2 & 0.8 & & & 1.6 & & & 1.4 \\
\hline $30 / 09 / 2010$ & 87.2 & 3.8 & 6.9 & & & & 1.5 & & \\
\hline $06 / 10 / 2010$ & 57.8 & 5.0 & 3.9 & & & & 1.8 & & \\
\hline $12 / 10 / 2010$ & 69.4 & 0.8 & 2.1 & & & 1.4 & & & \\
\hline $14 / 10 / 2010$ & 60.1 & & 0.7 & & & 1.3 & & & \\
\hline $15 / 10 / 2010$ & 49.1 & & & & & & & & \\
\hline $18 / 10 / 2010$ & 46.1 & 1.8 & 3.4 & & & & & & \\
\hline $19 / 10 / 2010$ & 75.0 & & 1.4 & & 1.3 & & & 1.0 & 0.8 \\
\hline $21 / 10 / 2010$ & 58.2 & 2.3 & 4.0 & & & & & & \\
\hline $23 / 10 / 2010$ & 65.9 & 0.3 & 1.9 & & 0.7 & & & 1.2 & 0.5 \\
\hline $26 / 10 / 2010$ & 56.5 & 1.0 & & & & & & & 0.9 \\
\hline $28 / 10 / 2010$ & 57.6 & 0.7 & 1.8 & & 1.7 & & & 1.8 & 0.6 \\
\hline $02 / 11 / 2010$ & 61.5 & 0.6 & 2.3 & & & & & 1.9 & 1.0 \\
\hline $03 / 11 / 2010$ & 69.5 & 2.5 & 3.4 & & & & & 0.4 & \\
\hline $04 / 11 / 2010$ & 79.4 & 0.6 & 0.6 & & & & & 0.4 & 0.7 \\
\hline 05/11/2010 & 58.9 & & & & & & & & \\
\hline $10 / 11 / 2010$ & 70.7 & & 0.5 & & & & & 0.5 & 0.4 \\
\hline $11 / 11 / 2010$ & 65.6 & 4.3 & 1.8 & & & & 1.1 & 1.6 & 1.7 \\
\hline
\end{tabular}

less easily traced back to sources. The sources of DON are more difficult to generalise and the magnitude of DON is likely to be the result of different contributions of biological and anthropogenic local origin and those deposited through long-range transport. Spring maxima of DON may be due to the release of pollen, plant debris and spores (Violaki et al., 2010), or spreading of manure and mineral $\mathrm{N}$ fertilisers (Neff et al., 2002; Zhang et al., 2012). Conversely, autumn maxima may be linked to decomposition of vegetation (Cape et al., 2004). The contribution of DON to TDN is low at Auchencorth $-10.0 \%$ in 2009 and $8.3 \%$ in 2010 - compared to the $24 \%$ (June 2005 to April 2007) measured at Bush Estate, an agricultural area $10 \mathrm{~km}$ north of Auchencorth Moss dominated by grazed grasslands with high stocking densities and receiving high rates of mineral nitrogen fertiliser ( $\sim 200 \mathrm{~kg} \mathrm{~N} \mathrm{ha}^{-1} \mathrm{yr}^{-1}$, Gonzalez Benitez et al., 2009). The literature average from a range of environments is $30 \%$ (Cornell et al., 2003; Cape et al., 2004, 2011; Zhang et al., 2008, 2012).

Previous studies of precipitation DIN and DON reported varying degrees of correlation between $\mathrm{DON}, \mathrm{NH}_{4}^{+}$and $\mathrm{NO}_{3}^{-}$. For example, Violaki et al. (2010) found no correlation between DON, $\mathrm{NH}_{4}^{+}$and $\mathrm{NO}_{3}^{-}$in wet deposition in the eastern Mediterranean. Zhang et al. (2008) also did not observe correlation between $\mathrm{DON}, \mathrm{NH}_{4}^{+}$and $\mathrm{NO}_{3}^{-}$in precipitation at 15 sites in China. However, when an additional 37 sites from across the globe were added to these data, positive relationships between DON and DIN were found, suggesting that broadly similar sources of DON and DIN exist at the global, but not regional, scale. In a number of studies, DON and $\mathrm{NH}_{4}^{+}$were correlated, or at least more closely correlated than DON and $\mathrm{NO}_{3}^{-}$, suggesting DON is more closely associated with agricultural sources than with combustion processes (Cape et al., 2004, 2011; Chen et al., 2008; Zhang et al., 2012). Our Auchencorth Moss study showed weak to moderate correlations between $\mathrm{NH}_{4}^{+}$and $\mathrm{NO}_{3}^{-}$but no correlation between DIN and DON. This suggests that whilst DIN compounds might share a common source (e.g. secondary aerosol), DON does not. This is further supported by the later seasonal maxima of DON compared to those of the DIN compounds (Cape et al., 2011).

\section{2 $\mathrm{N}$ in the soil solution}

Interestingly, the TDN and DIN deposited as precipitation in 2010 was larger than in 2009 , but the soil chemistry showed the opposite. The larger soil water DIN concentrations in 2009 may be due to the activities of sheep which grazed on this moorland at very low livestock density of less than 1 ewe per ha ${ }^{-1}$ and also a small herd of 15-20 cattle. In 2009, sheep and sheep droppings were observed in and around the vicinity of the dip wells and where the soil cores were collected from. The small cattle herd (15-20) also had access to this area. However, in 2010, there were no cattle on site and the sheep frequented another area of this large peatland. 


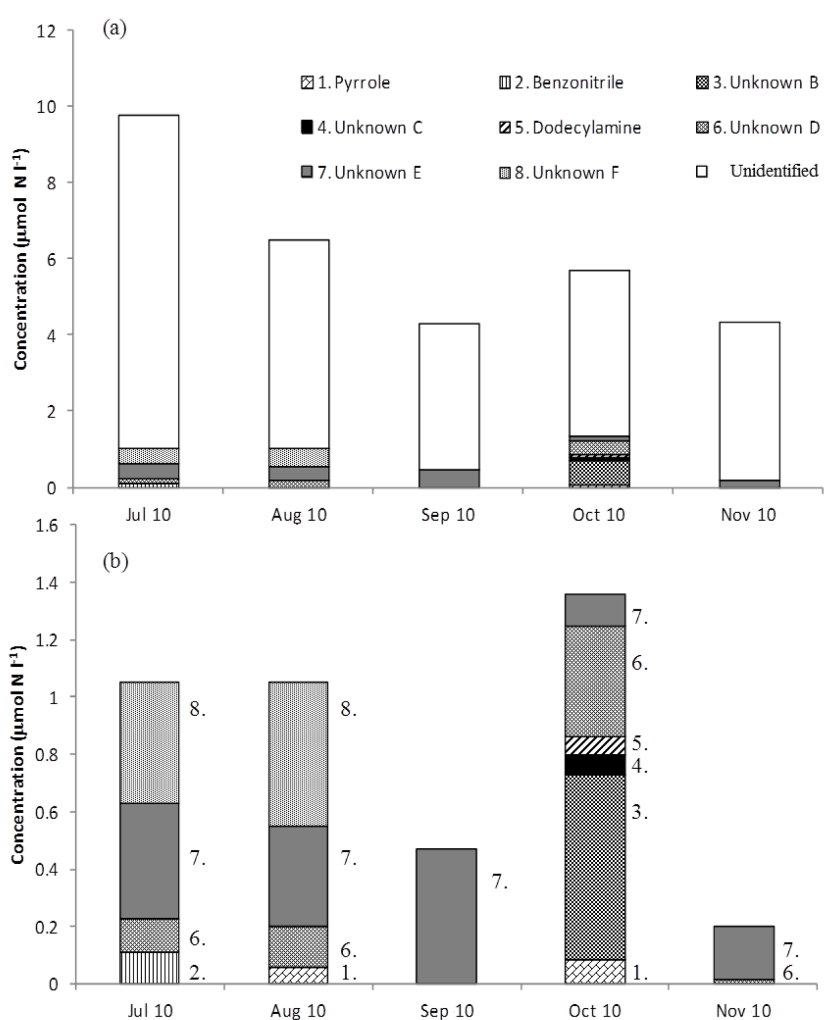

Figure 5. Mean monthly concentrations of the individual DON compounds found in precipitation water. Panel (a) includes the DON fraction identified from the Antek (white bar), whilst (b) excludes the unidentified fraction, so that the speciation achieved by $\mathrm{GC} \times \mathrm{GC}-\mathrm{NCD}$ is more clearly seen.

\subsection{The composition of $N$ in stream water}

DON is the dominant form of stream-water $\mathrm{N}$ in high rainfall areas, catchments with steep slopes and those draining peatlands. Typical DON contributions vary from 54 to $82 \%$ annually (Chapman et al., 2001; Cundill et al., 2007; Helliwell et al., 2007a), which is similar to the 75 and $74 \%$ measured in the Black Burn for 2009 and 2010 respectively. Mean annual $\mathrm{NH}_{4}^{+}$concentrations (22\% in 2009 and $19 \%$ in 2010) were larger than $\mathrm{NO}_{3}^{-}$concentrations $(3.6 \%$ in 2009 and $6.6 \%$ in 2010). This was also observed by Helliwell et al. (2007a) in four upland regions in the UK. Usually, the leaching of inorganic $\mathrm{N}$ is dominated by $\mathrm{NO}_{3}^{-}$, whereas $\mathrm{NH}_{4}^{+}$ remains in the soil in weak association with organic matter and incorporation into clay lattices (Scherer, 1993; Chapman and Edwards, 1999; Davies et al., 2005; Helliwell et al., 2007a).

A previous study carried out at the Black Burn in 2008, approximately $2.5 \mathrm{~km}$ downstream from the sampling site reported here, also found DON to be the dominant species (mean concentration of $47.9 \mu \mathrm{mol} \mathrm{N} \mathrm{L}{ }^{-1}$ ) contributing $71 \%$ of the TDN, followed by $\mathrm{NH}_{4}^{+}$(mean concentration $10.7 \mu \mathrm{mol} \mathrm{N} \mathrm{L}^{-1}$ ), contributing $16 \%$ of TDN and $\mathrm{NO}_{3}^{-}$
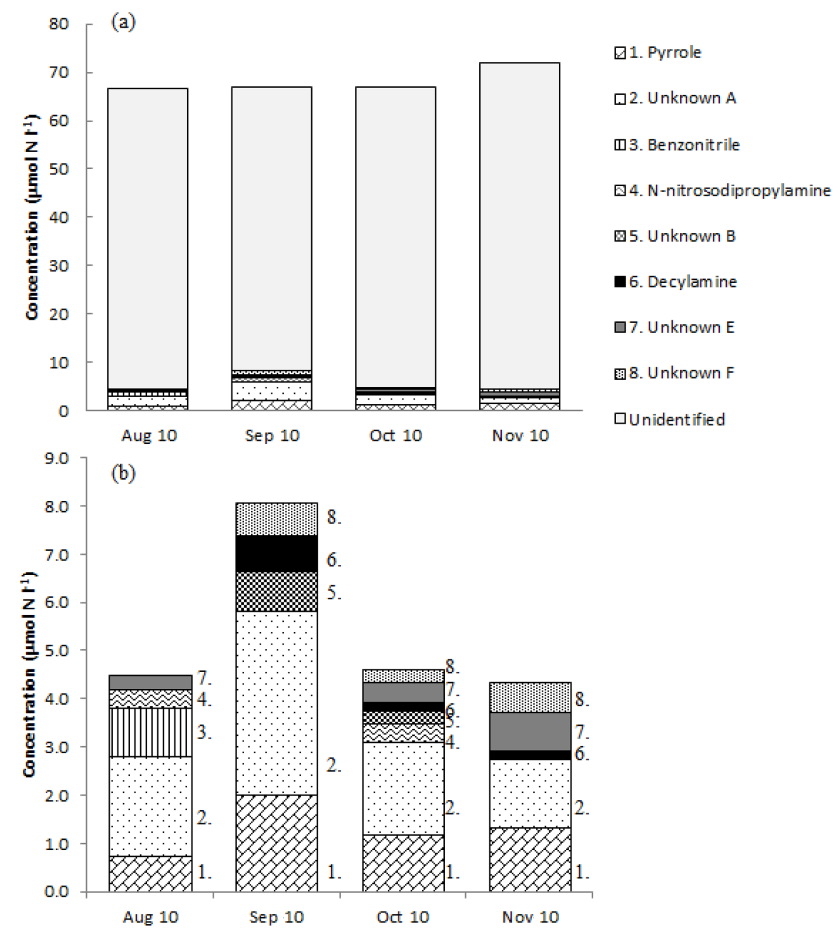

Figure 6. Mean monthly concentrations of the individual compounds found in stream water. Panel (a) includes the DON fraction identified from the Antek (white bar) and panel (b) excludes the unidentified fraction, so the fraction detected by GC $\times$ GC-NCD is more clearly seen.

(mean concentration $8.6 \mu \mathrm{mol} \mathrm{N} \mathrm{L}{ }^{-1}$ ), contributing $13 \%$ of TDN (Vogt, 2011). The DON values are comparable to the study reported here, but the Vogt study found lower $\mathrm{NH}_{4}^{+}$and higher $\mathrm{NO}_{3}^{-}$values. These differences may be due to the location of the Vogt study site, which was further downstream, next to a busy road and was frequented by sheep more regularly than our upstream site. No correlation was found between the wet deposition of atmospheric $\mathrm{N}$ and stream concentrations suggesting that precipitation does not represent a major source of stream-water $\mathrm{N}$.

\subsection{Seasonal patterns of $\mathrm{N}$ in stream water}

No clear seasonal pattern was identified for DON, although the general trend was higher concentrations in the warmer months. Also Chapman et al. (2001), who studied 28 Scottish upland streams, found DON to be larger in the summer than winter months. They suggested that this was due to an increase of in-stream biological DON production, mediated by algae and microorganisms, rather than increased leaching from the soil.

The seasonal pattern of $\mathrm{NO}_{3}^{-}$, where concentrations were higher in cooler months and lower in warmer months has been observed in numerous upland studies (Black et al., 1993; Chapman et al., 2001; Daniels et al., 2012). In warmer 
months, the biological uptake of $\mathrm{NO}_{3}^{-}$by plants and microbes both in the terrestrial and aquatic systems is at its highest, immobilising $\mathrm{NO}_{3}^{-}$. In winter, productivity declines, increasing the amount of $\mathrm{NO}_{3}^{-}$available to be leached into the stream and its residence time in the stream (Black et al., 1993; Chapman et al., 2001; Helliwell et al., 2007b). The summer peaks in June and July 2010 are unusual and different to the summer lows observed in 2009. The high June value appears to be due to one high concentration, skewing the mean monthly concentration; the median value for June was $0 \mu \mathrm{molNL} \mathrm{N}^{-1}$. The high July 2010 peak is also evident in the mean concentrations of DON and $\mathrm{NH}_{4}^{+}$, and is still reflected in median values. The reason for these high values are unclear, however the differences in discharge and precipitation between the two sampled years may be a contributing factor.

\subsection{DON speciation by GC x GC-NCD}

More than $82 \%$ of the DON was not trapped by the SPE cartridges. This low retention implies that further work is needed to improve the extraction procedure and maximise the applicability of this technique or alternatives, such as liquid-liquid extractions or stir-bar sorptive extraction, and thereby provide a more comprehensive picture of the DON species in precipitation and stream water. For example, it is noticeable that highly polar and large molecular weight DON species were not detected by the GC $\times$ GC-NCD, and presumably also not retained by the C18 SPE cartridges.

Whilst some of the compounds detected by the $\mathrm{GC} \times \mathrm{GC}$ NCD appear in precipitation and stream water, the two main compounds identified in the stream water were only present in precipitation in small amounts or not present at all. This suggested that at least some sources of DON in precipitation and stream water are different. Schulten and Schnitzer (1998) and Leinweber et al. (2013) investigated the chemistry of organic matter of humic substances and soils. Amongst other compounds they identified pyrrole and benzonitrile, along with derivatives of pyrrole. Pyrrole and pyrrolic compounds are a major $\mathrm{N}$ source in coal and are often found in peats (van Smeerdijk and Boon, 1987; Schulten and Schnitzer, 1998). It is therefore likely that the source of pyrrole in the streams was the peat in the surrounding catchment. Pyrrole has also been identified in fog waters, where it was found to be quickly degraded during transport by photochemistry (Anastasio and McGregor, 2000). It is thought to be present in the atmosphere originating from soil dust rich in humic/fluvic material (Schulten and Schnitzer, 1998; Anastasio and McGregor, 2000). This may explain the presence of a small amount of pyrrole found in the precipitation samples. The three other compounds identified were all amines: dodecylamine (found only in the precipitation), NDPA and decylamine (both only found in the stream). The number of unknown compounds detected may be reduced by running more standards for comparison.
In spite of the low DOC retention by the SPE cartridges, our attempt to describe the DON speciation in precipitation and streams suggests that further investigation could provide some insight into the temporal and sector-dependent speciation of DON and their sources.

\section{Conclusions}

DON is an important source of nitrogen in precipitation and stream water and must not be ignored in measurements of atmospheric nitrogen deposition rates or stream-water nitrogen balances. The mean volume-weighted concentration of DON found in the precipitation over the total study period was $4.8 \mu \mathrm{mol} \mathrm{N} \mathrm{L}^{-1}$, with a mean contribution of $9 \%$ to TDN.

DON in stream water was a major contributor to TDN (with an overall mean of $75 \%$ ) and showed no clear seasonal pattern. The presence of pyrrole, the large DON concentrations and the high $\mathrm{NH}_{4}^{+}$in stream water suggest mineralisation of organic $\mathrm{N}$ stored in peat was one of the sources.

In soil water, DON contributed an overall mean of $92 \%$ to TDN. The mean concentrations of DON did not vary greatly between the years but the concentration of $\mathrm{NH}_{4}^{+}$did ( $8.6 \mu \mathrm{mol} \mathrm{N} \mathrm{L}{ }^{-1}$ in 2009 and $0.2 \mu \mathrm{mol} \mathrm{N} \mathrm{L}^{-1}$ in 2010 ), possibly due to localised impact of animal waste and the importance of water table variation on the availability of $\mathrm{N}$ to plants and on immobilisation.

$\mathrm{GC} \times \mathrm{GC}-\mathrm{NCD}$ shows promise as a technique to identify compounds in stream water/precipitation and their potential sources, but requires further development.

Acknowledgements. This work was funded by the UK Natural Environment Research Council (NERC) through a PhD studentship grant number NE/H526351/1 and standard grant ((NE/F01905X/1) and the EU projects NitroEurope IP (FP6 proposal number 017841) and ECLAIRE "Effects of Climate Change on Air Pollution Impacts and Response Strategies for European Ecosystems" (FP7-ENV-2011/282910). The authors would like to gratefully acknowledge the assistance of Ian Leith, Ivan Simmons with sample collection and analysis, and Harwell Analytics laboratory for analysis of the EMEP samples.

Edited by: I. Trebs

\section{References}

Anastasio, C. and McGregor, K. G.: Photodestruction of dissolved organic nitrogen species in fog waters, Aerosol Sci. Tech., 32, 106-119, 2000.

Billett, M. F., Palmer, S. M., Hope, D., Deacon, C., StoretonWest, R., Hargreaves, K. J., Flechard, C., and Fowler, D.: Linking land-atmosphere-stream carbon fluxes in a lowland peatland system, Global Biogeochem. Cy., 18, GB1024, doi:10.1029/2003GB002058, 2004. 
Black, K. E., Lowe, J. A. H., Billett, M. F., and Cresser, M. S.: Observations on the changes in nitrate concentrations along streams in seven upland moorland catchments in Northeast Scotland, Water Res., 27, 1195-1199, 1993.

Calderon, S. M., Poor, N. D., and Campbell, S. W.: Estimation of the particle and gas scavenging contributions to wet deposition of organic nitrogen, Atmos. Environ., 41, 4281-4290, 2007.

Cape, J., Anderson, M., Rowland, A., and Wilson, D.: Organic nitrogen in precipitation across the United Kingdom, Water Air Soil Poll., 4, 25-35, 2004.

Cape, J. N., Cornell, S. E., Jickells, T. D., and Nemitz, E.: Organic nitrogen in the atmosphere - Where does it come from? A review of sources and methods, Atmos. Res., 102, 30-48, 2011.

Chapman, P. J. and Edwards, A. C.: The impact of atmospheric nitrogen deposition on the behaviour of nitrogen in surface waters, in: The Impact of Nitrogen Deposition on Natural and Semi-Natural Ecosystems, edited by: Langan, S. J., Kluwer Academic Publishers, Dordrecht, the Netherlands, 153-212, 1999.

Chapman, P. J., Edwards, A. C., and Cresser, M. S.: The nitrogen composition of streams in upland Scotland: some regional and seasonal differences, Sci. Total Environ., 265, 65-83, 2001.

Chen, N.-W., Hong, H.-S., and Zhang, L.-P.: Wet deposition of atmospheric nitrogen in Jiulong River Watershed, Huanjing Kexue, 29, 38-46, 2008.

Cheng, Y., Li, S.-M., and Leithead, A.: Chemical Characteristics and Origins of Nitrogen-Containing Organic Compounds in $\mathrm{PM}_{2.5}$ Aerosols in the Lower Fraser Valley, Environ. Sci. Technol., 40, 5846-5852, 2006.

Cornell, S. E.: Atmospheric nitrogen deposition: Revisiting the question of the importance of the organic component, Environ. Pollut., 159, 2214-2222, 2011.

Cornell, S. E., Jickells, T. D., Cape, J. N., Rowland, A. P., and Duce, R. A.: Organic nitrogen deposition on land and coastal environments: a review of methods and data, Atmos. Environ., 37, 21732191, 2003.

Cundill, A. P., Chapman, P. J., and Adamson, J. K.: Spatial variation in concentrations of dissolved nitrogen species in an upland blanket peat catchment, Sci. Total Environ., 373, 166-177, 2007.

Daniels, S. M., Evans, M. G., Agnew, C. T., and Allott, T. E. H.: Ammonium release from a blanket peatland into headwater stream systems, Environ. Pollut., 163, 261-272, 2012.

Davies, J. J. L., Jenkins, A., Monteith, D. T., Evans, C. D., and Cooper, D. M.: Trends in surface water chemistry of acidified UK Freshwaters, 1988-2002, Environ. Pollut., 137, 27-39, 2005.

Dinsmore, K. J.: Atmosphere-Soil-Stream Greenhouse Gas Fluxes from Peatlands, $\mathrm{PhD}$ thesis, The University of Edinburgh, Edinburgh, 2008.

Dinsmore, K. J., Billett, M. F., Skiba, U. M., Rees, R. M., Drewer, J., and Helfter, C.: Role of the aquatic pathway in the carbon and greenhouse gas budgets of a peatland catchment, Glob. Change Biol., 16, 2750-2762, 2010.

Dinsmore, K. J., Billett, M. F., and Dyson, K. E.: Temperature and precipitation drive temporal variability in aquatic carbon and GHG concentrations and fluxes in a peatland catchment, Glob. Change Biol., 10, 2133-2148, 2013.

Flechard, C. R. and Fowler, D.: Atmospheric ammonia at a moorland site. I: The meteorological control of ambient ammonia concentrations and the influence of local sources, Q. J. Roy. Meteorol. Soc., 124, 733-757, 1998.
Fowler, D., Pilegaard, K., Sutton, M. A., Ambus, P., Raivonen, M., Duyzer, J., Simpson, D., Fagerli, H., Fuzzi, S., Schjoerring, J. K., Granier, C., Neftel, A., Isaksen, I. S. A., Laj, P., Maione, M., Monks, P. S., Burkhardt, J., Daemmgen, U., Neirynck, J., Personne, E., Kruit, R. W., Bahl, K. B., Flechard, C., Tuovinen, J. P., Coyle, M., Gerosa, G., Loubet, B., Altimir, N., Gruenhage, L., Ammann, C., Cieslik, S., Paoletti, E., Mikkelsen, T. N., Poulsen, H. R., Cellier, P., Cape, J. N., Horváth, L., Loreto, F., Niinemets, Palmer, P. I., Rinne, J., Misztal, P., Nemitz, E., Nilsson, D., Pryor, S., Gallagher, M. W., Vesala, T., Skiba, U., Brüeggemann, N., Boltenstern, S. Z., Williams, J., O'Dowd, C., Facchini, M. C., de Leeuw, G., Flossman, A., Chaumerliac, N., and Erisman, J. W.: Atmospheric Composition Change: Ecosystems - Atmosphere interactions, Atmos. Environ., 43, 5193-5267, 2009.

Gonzalez Benitez, J. M., Cape, J. N., Heal, M. R., van Dijk, N., and Diez, A. V.: Atmospheric nitrogen deposition in south-east Scotland: Quantification of the organic nitrogen fraction in wet, dry and bulk deposition, Atmos. Environ., 43, 4087-4094, 2009.

Helliwell, R. C., Coull, M. C., Davies, J. J. L., Evans, C. D., Norris, D., Ferrier, R. C., Jenkins, A., and Reynolds, B.: The role of catchment characteristics in determining surface water nitrogen in four upland regions in the UK, Hydrol. Earth Syst. Sci., 11, 356-371, doi:10.5194/hess-11-356-2007, 2007a.

Helliwell, R. C., Davies, J. J. L., Evans, C. D., Jenkins, A., Coull, M. C., Reynolds, B., Norris, D., and Ferrier, R. C.: Spatial and seasonal variations in nitrogen leaching and acidity across four acid-impacted regions of the UK, Water Air Soil Poll., 185, $3-$ 19, $2007 \mathrm{~b}$.

Hertel, O., Reis, S., Skjøth, C. A., Bleeker, A., Harrison, R., Cape, J. N., Fowler, D., Skiba, U., Simpson, D., Jickells, T., Baker, A., Kulmala, M., Gyldenkærne, S., Sørensen, L. L., and Erisman, J. W.: Nitrogen processes in atmosphere, in: The European Nitrogen Assessment: Sources, Effects and Policy Perspectives, edited by: Sutton, M. A., Howard, C. M., Erisman, J. W., Billen, G., Bleeker, A., Grennfelt, P., van Grinsven, H., and Grizzetti, B., Cambridge University Press, Cambridge, UK, 117-210, 2011.

Leinweber, P., Kruse, J., Baum, K., Arcand, M. M., Knight, J. D., and Farrell, R.: Advances in Understanding Organic Nitrogen Chemistry in Soils Using State-of-the-art Analytical Techniques, Adv. Agron., 119, 83-151, 2013.

Mitchell, G. H. and Mykura, W.: The Geology of the Neighbourhood of Edinburgh, Memoir of the Geological Survey, Scotland, 3rd Edn., H.M.S.O. publishing, Edinburgh, 1962.

Neff, J. C., Holland, E. A., Dentener, F. J., McDowell, W. H., and Russell, K. M.: The origin, composition and rates of organic nitrogen deposition: A missing piece of the nitrogen cycle?, Biogeochemistry, 57, 99-136, 2002.

Nieder, R. and Benbi, D. K.: Carbon and Nitrogen in the Terrestrial Environment, ISBN: 978-1-4020-8432-4, Springer Verlag, Heidelberg, 432 pp., 2008.

Özel, M. Z., Hamilton, J. F., and Lewis, A. C.: New Sensitive and Quantitative Analysis Method for Organic Nitrogen Compounds in Urban Aerosol Samples, Environ. Sci. Technol., 45, 14971505, 2011.

Prospero, J. M., Barrett, K., Church, T., Dentener, F., Duce, R. A., Galloway, J. N., Ii, H. L., Moody, J., and Quinn, P.: Atmospheric Deposition of Nutrients to the North Atlantic Basin, Biogeochemistry, 35, 27-73, 1996. 
Russell, K. M., Galloway, J. N., Macko, S. A., Moody, J. L., and Scudlark, J. R.: Sources of nitrogen in wet deposition to the Chesapeake Bay region, Atmos. Environ., 32, 2453-2465, 1998.

Scherer, H. W.: Dynamics and availability of the non-exchangeable $\mathrm{NH}_{4}-\mathrm{N}$ : a review, Eur. J. Agron., 2, 149-160, 1993.

Schlesinger, W. H.: Biogeochemistry: An Analysis of Global Change, 2nd Edn., Academic Press, San Diego, California, London, 1997.

Schulten, H. R. and Schnitzer, M.: The chemistry of soil organic nitrogen: a review, Biol. Fert. Soils, 26, 1-15, 1998.

Skiba, U., Jones, S. K., Drewer, J., Helfter, C., Anderson, M., Dinsmore, K., McKenzie, R., Nemitz, E., and Sutton, M. A.: Comparison of soil greenhouse gas fluxes from extensive and intensive grazing in a temperate maritime climate, Biogeosciences, 10, 123-1241, doi:10.5194/bg-10-1231-2013, 2013.

Tian, Y. H., Yang, L. Z., Yin, B., and Zhu, Z. L.: Wet deposition N and its runoff flow during wheat seasons in the Tai Lake Region, China, Agr. Ecosyst. Environ., 141, 224-229, 2011.

van Smeerdijk, D. G. and Boon, J. J.: Characterisation of subfossil Sphagnum leaves, rootlets of ericaceae and their peat by pyrolysis-high-resolution gas chromatography-mass spectrometry, J. Anal. Appl. Pyroly., 11, 377-402, 1987.
Violaki, K., Zarbas, P., and Mihalopoulos, N.: Long-term measurements of dissolved organic nitrogen (DON) in atmospheric deposition in the Eastern Mediterranean: Fluxes, origin and biogeochemical implications, Mar. Chem., 120, 179-186, 2010.

Vogt, E.: Nitrogen fluxes at the landscape scale: A case study in Scotland, PhD thesis, The University of Edinburgh, Edinburgh, 2011.

Yan, X. W.: Sulfur and nitrogen chemiluminescence detection in gas chromatographic analysis, J. Chromatogr. A, 976, 3-10, 2002.

Yesmin, L., Gammack, S. M., Sanger, L. J., and Cresser, M. S.: Impact of atmospheric $\mathrm{N}$ deposition on inorganic- and organic$\mathrm{N}$ outputs in water draining from peat, Sci. Total Environ., 166, 201-209, 1995.

Zhang, Y., Zheng, L. X., Liu, X. J., Jickells, T., Cape, J. N., Goulding, K., Fangmeier, A., and Zhang, F. S.: Evidence for organic N deposition and its anthropogenic sources in China, Atmos. Environ., 42, 1035-1041, 2008.

Zhang, Y., Song, L., Liu, X. J., Li, W. Q., Lu, S. H., Zheng, L. X., Bai, Z. C., Cai, G. Y., and Zhang, F. S.: Atmospheric organic nitrogen deposition in China, Atmos. Environ., 46, 195-204, 2012. 